\title{
Perbedaan Ketinggian Tempat Terhadap Pertambahan Bobot Badan Kambing Peranakan Etawa (Pe) Jantan Lepas Sapih
}

\author{
Oleh: \\ Nita Opi Ari Kustanti, S.Pt, MMA \\ Fakultas Peternakan, Universitas Islam Balitar \\ Jl. Mojopahit No.4 Blitar, Jawa Timur
}

\begin{abstract}
Etawa Cross Goat (PE) is a kind of a goat. It is a cross breed between Etawa and Kacang goat. Climate, Temperature and Humidity are the important factors to increase the weight of a goat. Some kinds of goat are spread in a mountain range or plateau because the goat is like it.

Problem of research is the effect of different site in increasing the weight of weaned male Etawa Cross Goat. Objective of study: To investigate the effect of different site to the weight of weaned male Etawa cross Goat. Method of study: This study is using Experimental design. It is intended to find out the effect of different site to the weight of weaned male Etawa Cross Goat. The technique of data analysis is using T-Test.

The finding of study was that the $t_{\text {count }}=(0,11)$. Standard deviation of the goat on the plateau is $S_{1}=1,25$ and the standard deviation on the goat on lowland is $S_{2}=0,81$. This means that there was not significant different weight of weaned male Etawa Cross goat which is live on plateau and on lowland.
\end{abstract}

Key words: Etawa Cross Goat, Different Site, Animal Weight

\section{Pendahuluan}

Kambing merupakan jenis ternak ruminansia yang sudah sejak lama dibudidayakan. Memelihara ternak ini relatif tidak sulit, karena selain jinak makanannya juga cukup beragam. Berbagai jenis hijauan mau dimakannya bahkan di beberapa daerah kambing memakan berbagai macam limbah rumah tangga bahkan mau memakan kertas Koran (Sasongko; Luh Gde; Tanda,; Achmad; Nurul, 2009). Ternak kambing sudah menyebar di seluruh Indonesia, Hal ini menunjukkan bahwa kambing mempunyai potensi cepat menyesuaikan diri dengan baik pada lingkungan dan kultur masyarakat Indonesia. Kambing mempunyai beberapa kelebihan diantaranya : mempunyai daya tahan lebih terhadap beberapa penyakit. Selain itu kambing memiliki daya seleksi yang lebih efektif dalam kondisi pengembalaan dibandingkan dengan jenis ternak lain.

Kambing Peranakan Etawa (PE) merupakan kambing hasil persilangan antara Kambing Etawa dan Kambing Kacang. Persilangan ini menghasilkan bentuk tubuh gabungan antara Kambing Etawa dan Kambing Kacang. Hasil persilangan ini banyak menimbulkan variasi sifat fisik dan fungsi ternak yang dihasilkan. Sifat dan fungsi dari hasil persilangan tersebut ada pula yang mendekati sifat Kambing Kacang dan ada pula yang mendekati ke arah Kambing Etawa. Kambing Peranakan Etawa (PE) berukuran hampir sama dengan kambing etawa namun lebih adaptif terhadap lingkungan lokal Indonesia.

Beberapa jenis kambing di Indonesia tersebar di daerah yang tergolong kering dan berbukit atau daerah pegunungan karena hewan ini menyukai daerah seperti itu, kambing adalah hewan yang takut pada air. Factor lingkungan yang mempengaruhi produksi ternak meliputi lingkungan fisik (radiasi, suhu udara, kelembaban, kecepatan angin, curah hujan, dan ketinngian tempat), lingkungan biotic (vegetasi, predator, hewan/ternak lain, bakteri, parasit, 
dan virus), lingkungan kimiawi (pencemaran dan peracunan oleh unsur-unsur) dan lingkungan manusia sebagai pengelola (Kadarsih, 2004). Semakin tinggi letak suatu daerah dari atas permukaan laut maka akan semakin rendah suhu udara rata-rata hariannya.

Dataran tinggi (disebut juga "plateau" atau "plato") adalah dataran yang terletak pada ketinggian diatas $700 \mathrm{~m}$ dpl. Dataran tinggi terbentuk sebagai hasil erosi dan sedimentasi. Dataran tinggi bisa juga terjadi oleh bekas kaldera luas, yang tertimbun material dari lereng gunung sekitarnya (Wikipedia, 2013). Yang dimaksud dengan ketinggian tempat adalah ketinggian dari permukaan air laut (elevasi). Ketinggian tempat memengaruhi perubahan suhu udara, semakin tinggi suatu tempat, misalnya pegunungan, semakin rendah suhu udaranya atau udaranya semakin dingin. Semakin rendah daerahnya semakin tinggi suhu udaranya atau udaranya semakin panas. Oleh karena itu ketinggian suatu tempat berpengaruh terhadap suhu suatu wilayah.

Dataran rendah adalah hamparan luas tanah dengan tingkat ketinggian yang di ukur dari permukaan laut adalah relatif rendah (sampai dengan $200 \mathrm{~m} \mathrm{dpl).} \mathrm{Istilah} \mathrm{ini} \mathrm{diterapkan} \mathrm{pada}$ kawasan manapun dengan hamparan yang luas dan relatif datar yang berlawanan dengan dataran tinggi. Suhu udara di dataran rendah, khususnya untuk wilayah Indonesia berkisar antara 23 derajat Celsius sampai dengan 28 derajat Celsius sepanjang tahun.

Kambing Peranakan Etawa (PE) merupakan kambing hasil persilangan antara kambing Etawa (Jamnapari) dengan kambing Kacang. Persilangan antara kedua kambing ini terjadi pada zaman penjajahan pemerintah Belanda di Indonesia. Hasil persilangan kambing ini menghasilkan ternak kambing dengan produksi tipe dwiguna (penghasil susu dan daging). Jumlah susu yang diproduksi setiap tahun selalu belum mampu memenuhi permintaan susu nasional. Produksi susu segar Indonesia tahun 2007 dan 2008 (sementara) sebesar 567.683 574.406 ton (Maupa, 2010). Kemampuan produksi susu dalam negeri yang masih rendah tersebut menghendaki perlunya optimalisasi potensi ternak-ternak perah dan tidak hanya mengandalkan sapi-sapi perah sebagaimana yang terjadi selama ini. Dalam perkembangannya kambing Peranakan Etawa (PE) dijadikan juga sebagai ternak penghasil susu yang potensial. Sutama (1998) melaporkan kambing Peranakan Etawa (PE) mempunyai produksi susu berkisar dari $1,5-3,5$ 1/hari.

Pengembangan kambing perah dalam upaya peningkatan produksi susu tidak terlepas dari faktor-faktor yang mempengaruhi kemampuan berproduksi susu ternak perah umumnya. Selain dari faktor genetik dan gizi makanan (kuantitas dan kualitas), lingkungan merupakan faktor yang tidak dapat diabaikan dalam mempengaruhi kemampuan bereproduksi susu ternak perah. Faktor lingkungan mempunyai aspek terhadap kemampuan kambing Peranakan Etawa (PE) untuk berproduksi susu. Dalam tulisan ini dicoba diungkapkan sejauh mana aspek lingkungan terhadap kemampuan berproduksi susu kambing Peranakan Etawa (PE).

Berdasarkan uraian diatas maka dilakukan penelitian Analisis Perbedaan Ketinggian Tempat Terhadap Pertambahan Bobot Badan Kambing Peranakan Etawa (PE) Jantan Lepas Sapih.

\section{Materi Dan Metode Penelitian}

Penelitian ini dilaksanakan pada tanggal 15 Juni 2013 sampai dengan 15 Juli 2013, di Kelompok Peternakan Kambing Peranakan Etawa (PE) di daerah Perkebunan Ngusri Kecamatan Gandusari Kabupaten Blitar dan kelompok Peternakan Kambing Peranakan Etawa (PE) di daerah Tumpang Kecamatan Talun Kabupaten Blitar.

\section{Materi Penelitian}


Materi Penelitian adalah kambing Peranakan Etawa (PE) jantan lepas sapih terdiri dari 10 ekor di dataran tinggi dan 10 ekor di dataran rendah yang mempunyai catatan lengkap, berumur 3-6 bulan.

\section{Metode Penelitian}

Metode pengambilan data dengan survey primer dilakukan dengan wawancara kepada kelompok Peternakan Kambing Peranakan Etawa (PE) di daerah Perkebunan Ngusri Kecamatan Gandusari Kabupaten Blitar dan desa Tumpang Kecamatan Talun Kabupaten Blitar. Selain itu juga dilakukan observasi lapangan untuk data pendukung bagi penelitian. Data sekunder diperoleh dari kajian literatur-literatur yang berkaitan dengan penelitian yang dilakukan.

Variabel pada penelitian ini ada dua yaitu variabel dependent dan variabel independent. Variabel dependent pada penelitan ini adalah perbedaan lokasi peternakan sedangkan variabel independent pada penelitian ini adalah perkembangan bobot badan kambing Peranakan Etawa (PE) jantan lepas sapih.

Analisis data dilakukan setelah data terkumpul kemudian menggunakan analisis kuantitatif. Analisis kuantitatif yang digunakan dalam penelitian adalah analisis deskriptif yang digunakan untuk mengetahui pertambahan bobot badan kambing Peranakan Etawa (PE) jantan lepas sapih. Untuk mengetahui perbedaan bobot badan kambing Peranakan Etawa (PE) di daerah dataran tinggi dan dataran rendah digunakan Uji T. Rumus yang digunakan adalah sebagai berikut:

$$
\begin{aligned}
\mathrm{t} & =\frac{\overline{x_{1}}-\overline{x_{2}}}{\sqrt[s]{\frac{1}{n_{1}}+\frac{1}{n_{2}}}} \\
\mathrm{~s}^{2} & =\frac{\left(n_{1}-1\right) s_{1}{ }^{2}+\left(n_{2}-1\right) s_{2}{ }^{2}}{n_{1}+n_{2}-2}
\end{aligned}
$$

Keterangan:

$\mathrm{t}=$ Parameter yang di ukur

$\mathrm{x}_{1}=$ Rata-rata bobot badan kambing PE di dataran tinggi

$\mathrm{x}_{2}=$ Rata-rata bobot badan kambing PE di dataran tinggi

$\mathrm{s}^{2}=$ Simpangan baku rataan

$\mathrm{s}_{1}=$ Simpangan baku kambing PE di dataran tinggi

$\mathrm{s}_{2}=$ Simpangan baku kambing PE di dataran rendah

$\mathrm{n}_{1}=$ Banyaknya jumlah kambing PE di dataran tinggi

$\mathrm{n}_{2}=$ Banyaknya jumlah kambing PE di dataran rendah

\section{Hasil Pengamatan Dan Pembahasan}

Pertumbuhan pada kambing adalah perubahan bentuk atau ukuran seekor ternak yang dapat dinyatakan dengan panjang, volume ataupun massa. Pertumbuhan dapat dinilai sebagai peningkatan tinggi, panjang, ukuran lingkar dan bobot yang terjadi pada seekor ternak muda yang sehat serta diberi pakan, minum dan mendapat tempat berlindung yang layak (Nurjulianto, 2012). Peningkatan sedikit saja ukuran tubuh akan menyebabkan peningkatan yang proporsional dari bobot tubuh, karena bobot tubuh merupakan fungsi dari volume. Pertumbuhan ternak dapat dibedakan menjadi pertumbuhan sebelum kelahiran (prenatal) dan pertumbuhan setelah terjadi kelahiran (postnatal). Pertumbuhan postnatal biasanya dibagi menjadi pertumbuhan pra sapih dan pasca sapih. Pertumbuhan pra sapih sangat tergantung pada 
jumlah dan mutu susu yang dihasilkan oleh induknya pada kambing, pertumbuhan pra sapih dipengaruhi oleh bobot lahir, produksi susu induk, umur induk, jenis kelamin anak dan umur penyapihan. Pertumbuhan pasca sapih (lepas sapih) sangat ditentukan oleh bangsa, jenis kelamin, mutu pakan yang diberikan, umur dan bobot sapih serta lingkungan seperti suhu udara, kondisi kandang, pengendalian parasit dan penyakit lainnya. Adanya variasi dalam usaha peternakan kambing perah dipengaruhi oleh banyak faktor di antaranya sistem pemberian makanan, sistem perkandangan dan lingkungan. Lingkungan adalah sesuatu yang sangat luas, mengacu pada semua faktor selain genetik, yang mempengaruhi produktivitas dan kesehatan seekor ternak (maupa,2010).

Faktor lingkungan adalah faktor yang memberikan pengaruh cukup besar terhadap tingkat produksi. Di antara sekian banyak komponen faktor lingkungan yang paling nyata pengaruhnya terhadap pertumbuhan kambing, adalah temperatur yang selalu berkaitan erat dengan kelembaban yang nyaman (comfort zone), dengan batas maksimum dan minimum temperatur dan kelembaban lingkungan berada pada thermoneutral zone. Di luar kondisi ini kambing akan mengalami stress.

Manfaat rumput adalah sebagai sumber tenaga atau energy dengan sedikit kandungan protein Jenis rumput yang umum di gunakan peternak adalah rumput alam (rumput lapangan). Selain rumput, sisa hasil pertanian juga dapat digunakan sebagai sumber tenaga atau energy. (Sasongko; Luh Gde; Tanda,; Achmad; Nurul, 2009). Pakan yang digunakan di peternakan tempat penelitian yaitu di daerah Ngusri dan Tumpang adalah hijauan/rumput-rumputan karena didaerah tersebut sangat mudah untuk mendapatkan pakan yang berupa hijauan/rumputrumputan tanpa diberi pakan tambahan (konsentrat).

Kebutuhan zat makanan pada ternak dipengaruhi oleh suhu dan kelembaban, pada suhu dan kelembaban tinggi, dapat menyebabkan menurunnya konsumsi pakan dan akan disertai dengan menurunnya daya cerna diikuti kehilangan berat badan dan menurunnya resistensi terhadap penyakit. Dengan adanya suhu lingkungan yang tinggi maupun yang lebih rendah dari suhu tubuhnya maka ternak akan berusaha mempertahankan suhu tubuhnya yang konstan.

Apabila dihadapkan pada cekaman panas, prioritas tingkah laku kambing Peranakan Etawa (PE) akan berubah. Konsekuensi yang cepat adalah mengurangi konsumsi pakan dan energi metabolis yang tersedia. Gangguan lain terhadap keseimbangan energi berasal dari perubahan fisiologis, endokrin dan pencernaan yang selanjutnya menurunkan energi yang tersedia, dan sebagai konsekuensinya menurunkan produksi ternak.

\section{Kesimpulan Dan Saran}

Berdasarkan dari hasil penelitian ini dapat disimpulkan bahwa ketinggian tempat tidak berpengaruh secara signifikan terhadap bobot badan kambing PE jantan lepas sapih yang berumur diantara 3-6 bulan. Data tersebut didukung oleh penghitungan rata-rata dan standard deviasi Pertambahan Bobot Badan (PBB) tiap wilayah yaitu sebagai berikut: Rata-rata bobot badan kambing di dataran tinggi $\left(\bar{X}_{1}\right)$ sebesar 16,25 dan rata-rata bobot badan kambing di dataran rendah $\left(\bar{X}_{2}\right)$ sebasar 16,2. Sedangkan Standard Deviasi kambing PE di dataran tinggi $\left(S_{1}\right)$ sebesar 1,25 dan Standard Deviasi kambing PE di dataran rendah $\left(S_{2}\right)$ sebesar 0,81.

\section{Saran}

Berdasarkan dari hasil penelitian ini saran yang dapat peneliti berikan adalah:

1. Untuk peternak: supaya para peternak lebih bisa meningkatkan perhatiannya tentang tempat dan pakan yang akan digunakan untuk memelihara ternak, khususnya peternak kambing Peranakan Etawa.

2. Untuk peneliti selanjutnya: Disarankan untuk melakukan penelitian lanjutan dengan jumlah sampel yang lebih banyak dan dengan tingkat umur yang berbeda. 


\section{Daftar Pustaka}

Anonymous, 2013. Budidaya Ternak Kambing. Ttg Budidaya Peternakan.

Hanum, R. 2002. Pengembangan Peternakan Terpadu Kambing dan Cokelat di Lampung Selatan. Lampung

Maupa, Z. 2010. Pengaruh Lingkungan Terhadap Produktivitas Kambing Peranakan Etawa $(P E)$.

Mistar, J. 2012. Handouts Statistics For Language Teaching Studies. Malang: Universitas Islam Malang.

Nurjulianto, Fl. 2012. Pertumbuhan Dan Perkembangan Kambing Dan Domba. Makasar: Universitas Hasanuddin.

Setiawati, T. 2013. Tampilan Bobot Badan Dan Ukuran Tubuh Kambing Dara Peternakan Etawa Akibat Pemberian Ransum Dengan Suplementasi Urea Yang Berbeda. Animal Agricultural Journal, Vol.2.2013. Semarang: Universitas Diponegoro.

Sulaksana, I. 2008. Pertumbuhan Anak Kambing Peranakan Etawa (PE) Sampai Umur 6 Bulan di Pedesaan. Jurnal Ilmiah Ilmu-Ilmu Peternakan, vol.X.No.3. Jambi: Universitas Jambi.

Supriyati. 2012. Pertumbuhan Kambing Peranakan Etawa Prasapih Yang Diberi Susu Pengganti. Bogor: Balai Penelitian Ternak.

Utomo. 2013. Pengaruh Perbedaan Ketinggian Tempat Terhadap Capaian Hasil Inseminasi Buatan Pada Kambing Peranakan Ettawa. SAINS Peternakan Vol. 11 (1). Yogyakarta: Universitas Mercu Buana Yogyakarta.

Wijoseno, Luh Gde, Tanda, Achmad, Nurul. 2009. Beternak Kambing Intensif. Nusa Tenggara: Balai Pengkajian Teknologi Pertanian Nusa Tenggara Barat. 